\title{
Józef Pieter - pedagog, psycholog, organizator szkolnictwa wyższego na Górnym Śląsku
}

\author{
Józef Pieter - Educator, Psychologist, Organiser \\ of Higher Education in Upper Silesia
}

Professor Józef Pieter (1904-1989) was a Polish psychologist, philosopher, pedagogue, logologist, researcher, and lecturer at the Jagiellonian University, University of Łódź, University of Warsaw, University of Silesia, Pedagogical University in Katowice, and Central Institute of Physical Education - Academy of Physical Education in Warsaw. He was born in Ochaby in Cieszyn Silesia. He graduated from the Jagiellonian University, where he studied philosophy and history and where he also obtained his doctoral degree. In 1945, he was habilitated at the University of Poznań. He is the author of over 200 scientific publications, including over 40 books, in the field of pedagogy and psychology. An educator of many teachers and scientists. He supervised over 20 doctorates.

Professor Józef Pieter was a person with outstanding merits for the development of higher education in Upper Silesia. He was aware that Upper Silesia did not have a university - an institution necessary for the intellectual development of the population - which could contribute to strengthening the Polishness of the inhabitants. He was fond of this idea throughout his life. After World War II, he became involved in the organisation of scientific life in Upper Silesia. For several years he held, among others, the post of the rector of WSP (Pedagogical University) in Katowice. His actions, despite many unfavourable circumstances resulting from the existing political situation, eventually contributed to the establishment of the University of Silesia in Katowice. The following article aims to present Prof. Pieter's profile - mainly his merits for the organization of higher education but also his scientific achievements, which in many respects were both innovative and at a world-class level.

Keywords: psychology, pedagogy, higher education in Upper Silesia

Słowa kluczowe: psychologia, pedagogika, szkolnictwo wyższe na Górnym Śląsku 


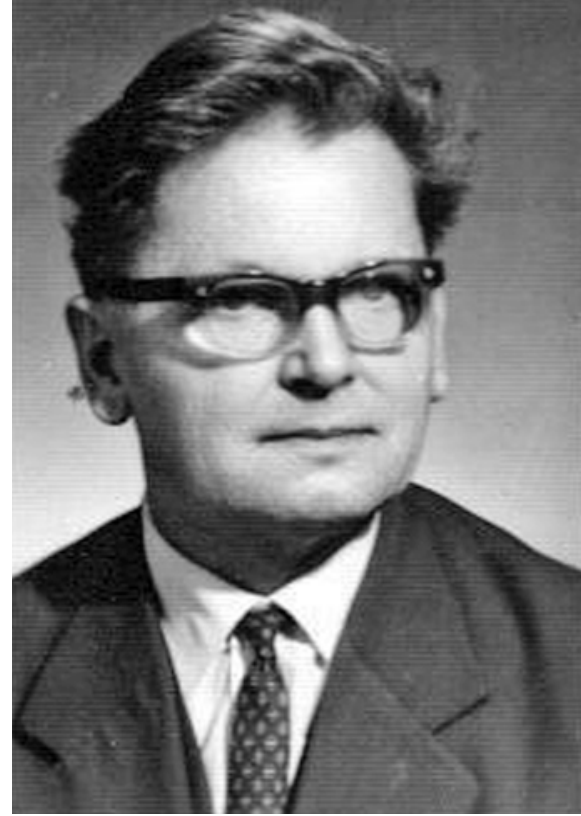

Ryc. 1. Józef Pieter (zdjęcie udostępnione przez rodzinę).
Prof. Józef Pieter (1904-1989) był postacią nietuzinkową, niezwykle zasłużoną dla rozwoju szkolnictwa wyższego na Górnym Śląsku. Należał do tej nielicznej grupy mieszkańców polskiego Śląska, którym udało się zdobyć wyższe wykształcenie. Bardzo szybko zdał sobie sprawę, że kraina jego urodzenia nie posiada wyższej uczelni typu uniwersyteckiego, która jego zdaniem była niezbędna do rozwoju intelektualnego zamieszkującej ją ludności oraz mogłaby przyczynić się do ugruntowania polskości jej mieszkańców. Idea ta była mu bliska przez całe życie. Jako rektor Wyższej Szkoły Pedagogicznej w Katowicach postawił sobie za cel przekształcenie jej w uniwersytet. Jego działania pomimo wielu niesprzyjających czynników, wynikających z istniejącej sytuacji politycznej, przyczyniły się $w$ końcu do powołania Uniwersytetu Śląskiego. Pomimo niewątpliwych zasług nie powierzono mu jednak funkcji rektora nowo powstałej uczelni, co było skutkiem jego postawy w okresie protestów studenckich w 1968 r. oraz negatywnego stosunku do komunizmu. Został niejako „odstawiony na boczny tor".

Niniejszy artykuł ma na celu ukazanie sylwetki prof. Pietera, głównie jego zasług dla organizacji szkolnictwa wyższego, ale również jego dokonań naukowych, które w wielu aspektach były nie tylko nowatorskie, lecz także stały na najwyższym światowym poziomie.

Józef Pieter urodził się 19 lutego 1904 r. w Ochabach na Śląsku Cieszyńskim w katolickiej rodzinie Józefa i Alojzy z domu Poloczek. Jego ojciec pracował jako cieśla a później majster ciesielski. W 1914 r., kilka tygodni przed wybuchem wojny, rodzina przeniosła się z Ochab do nowego domu w Skoczowie. Edukację rozpoczął w 1910 r. w szkole ludowej w Ochabach. Kontynuował ją od września 1913 r. w szkole ludowej i wydziałowej w Skoczowie ${ }^{2}$.

Podczas nauki w szkole ludowej i wydziałowej podjął starania o przyjęcie do polskiego Gimnazjum Klasycznego im. A. Osuchowskiego w Cieszynie, prowadzonego przez Macierz Szkolną, do którego zaczął uczęszczać od września 1916 r. $^{3}$ W przygotowaniach do

1 Muzeum im. Gustawa Morcinka w Skoczowie [dalej: Muzeum w Skoczowie], Dokumenty zdeponowane przez rodzinę prof. Józefa Pietera. Odpis świadectwa urodzenia i chrztu Józefa Pietera potwierdzony dnia 27.02.1933 przez sekretarza Uniwersytetu Jagiellońskiego; E. Pieter-Kania, Droga życia prof. zw. dr. hab. Józefa Pietera mojego Ojca, [w:] Prof. zw. dr. hab. Józef Pieter. Działalność i dzieła. Materiały posesyjne, Katowice 1999, s. 9; Pieter Józef, prof. dr. hab. (biogram), [w:] Non omnis moriar. Zmarli Pracownicy Uniwersytetu Śląskiego w Katowicach 1968-2008, red. A. Barciak, Katowice 2008, s. 282. Muzeum w Skoczowie, Świadectwo ze szkoły (niemieckiej) w Skoczowie z roku szkolnego 1915/16.

3 Szerzej patrz: Księga Pamiątkowa Polskiego Gimnazjum Macierzy Szkolnej w Cieszynie obecnie Liceum Ogólnokształcącego imienia Antoniego Osuchowskiego w Cieszynie wydana z okazji 100. rocznicy założenia szkoły, 
egzaminu wstępnego do gimnazjum pomagał mu ówczesny katecheta skoczowski ks. Ludwik Kojzar. W latach edukacji gimnazjalnej mieszkał w „Internacie im. błogosławionego Melchiora Grodzieckiego" na Bobrku, a następnie w internacie w samym Cieszynie przy ul. Sarkandra4. Do cieszyńskiego gimnazjum Józef Pieter uczęszczał osiem lat. Gimnazjum pozwoliło mu na zdobycie solidnej wiedzy, ugruntowało również jego poczucie polskości ${ }^{5}$. Już wtedy zainteresowała go filozofia. Gimnazjum ukończył z wyróżnieniem w 1924 r. Maturę zdał 28 czerwca ${ }^{6}$.

Po maturze Pieter „wpisał" się na studia na Wydziale Filozoficznym Uniwersytetu Jagiellońskiego w Krakowie ${ }^{7}$. Podjął jednocześnie studia z historii, filologii klasycznej i filozofii klasycznej. Preferował samodzielne studiowanie, chłonąc wiedzę z książek. Nadal szczególnie interesowała go filozofia. Już we wrześniu 1924 r. zapisał się do Koła Filozoficznego UJ, w którym pełnił kolejno funkcje: skarbnika, bibliotekarza a w roku akademickim 1927/1928 - prezesa ${ }^{8}$. Pod wpływem dzieł Bertranda Russella w 1925 r. ponownie zainteresował się matematyką. We wrześniu 1927 r. wziął udział w Kongresie Filozoficznym w Warszawie, na którym publicznie wygłosił pierwszy referat poza środowiskiem uniwersyteckim, zatytułowany Obrona krytycznego realizmu. Z kolei pod wpływem prof. Władysława Heinricha zainteresował się psychologią - zwłaszcza etyką i filozofią wartości ${ }^{9}$. Ponadto interesowała go pedagogika, szczególnie metody oceniania wiedzy ${ }^{10}$. W 1928 r. doktoryzował się z filozofii u prof. Witolda Rubczyńskiego na podstawie pracy pt. Analiza i krytyka filozofii wartości Hugona Münsterberga na tle współczesnej aksjologii. Pomimo że nie uzyskał wtedy jeszcze absolutorium ze studiów w Uniwersytecie Jagiellońskim, został promowany na doktora 6 marca 1928 r. ${ }^{11}$ Pokłosiem dysertacji były artykuły publikowane na łamach „Przeglądu Filozoficznego”, „Etyki”, „Kultury i wychowania", poświęcone psychologii społecznej i wychowawczej, pedagogice oraz historii myśli filozoficznej i społecznej ${ }^{12}$. Wtedy też zainteresował się warunkami życia młodzieży i ludzi dorosłych w środowiskach społecznych ${ }^{13}$. W 1928 r. zakończył również studia historyczne uzyskaniem magisterium na podstawie pracy dyplomowej napisanej pod kierunkiem prof. Ludwika Piotrowicza, poświęconej historii Cypru pod panowaniem dynastii Euagorytów w Salaminie ${ }^{14}$.

Cieszyn 1995; Księga pamiątkowa Gimnazjum Polskiego w Cieszynie, obecnie Liceum Ogólnokształcącego im. A. Osuchowskiego w Cieszynie, Katowice 1960.

4 K. Szczurek, Szkoła w swoim stuleciu, [w:] Księga Pamiątkowa Polskiego Gimnazjum Macierzy Szkolnej, s. 15-16; Księga pamiątkowa Gimnazjum Polskiego w Cieszynie, s. 20, 38.

5 Ibid., s. 18.

6 Muzeum w Skoczowie, Świadectwo dojrzałości z dnia 28.06.1924; Wykazy absolwentów za 100 lat, [w:] Księga Pamiątkowa Polskiego Gimnazjum Macierzy Szkolnej, s. 199; J. Pieter, Czasy i ludzie, t. 1, Katowice 1986, s. 180; E. Pieter-Kania, op. cit., s. 9.

7 Muzeum w Skoczowie, Książeczka legitymacyjna nr 588 studenta Wydziału Filozoficznego UJ; S. Fertacz, Na drodze do uniwersytetu, [w:] Mądrość zbudowała sobie dom... Uniwersytet Śląski 1968-2008. Dzieje, dokumentacja, źródła, red. A. Barciak, Katowice 2008, s. 29.

8 J. Pieter, Czasy i ludzie, t. 1, s. 200.

9 Ibid., s. 201-202.

10 W. Bobrowska-Nowak, Wkład prof. Józefa Pietera w rozwój pedagogiki i psychologii wychowania i nauczania oraz historii psychologii, [w:] Prof. zw. dr. hab. Józef Pieter. Działalność $i$ dzieła. Materiały posesyjne, s. 13

11 Muzeum w Skoczowie, Dyplom doktora filozofii wydany 07.03.1928 przez Uniwersytet Jagielloński; Pieter Józef, prof. dr. hab. (biogram), s. 282.

12 W. Bobrowska-Nowak, op. cit., s. 14.

13 Ibid., s. 13.

14 Pieter Józef, prof. dr. hab. (biogram), s. 282. 
Po studiach uzyskał etat w Gimnazjum Miejskim w Żorach, gdzie pracował od stycznia do czerwca 1929 r. jako nauczyciel języka polskiego, historii i łaciny. W związku z podjęciem studiów pedagogicznych formalnie otrzymał urlop płatny od 1 września 1929 r. do września 1931 r. jako nauczyciel pełnoetatowy w Seminarium Nauczycielskim w Nowej Wsi ${ }^{15}$. W latach 1929-1931 odbył studia pedagogiczne i psychologiczne w Krakowie, w Studium Pedagogicznym UJ.

Jego „mistrzem” w psychologii był w tym czasie prof. Stefan Szuman, a w pedagogice prof. Zygmunt Mysłakowski. Ten ostatni zainteresował go filozofią wychowania Johna Deweya. W rezultacie Pieter został czołowym znawcą Deweya w Polsce ${ }^{16}$. Efektem były artykuły poświęcone światopoglądowi młodzieży oraz wpływowi środowiska społecznego na rozwój inteligencji u dzieci ${ }^{17}$. Na seminarium prof. Szumana zgłębiał problematykę testów psychologicznych oraz cech znamiennych dzieci i młodzieży. Zapoznał się wtedy z poglądami Jeana Piageta, Charlotte Bühler, Alfreda Bineta oraz Williama Sterna. Studia zwieńczył w 1931 r. magisterium z pedagogiki z zakresu psychologii wychowawczej na podstawie pracy napisanej pod kierunkiem prof. Szumana pt. Testy wiadomości szkolnych - testy pedagogiczne. Po złożeniu egzaminów przed Komisją Egzaminacyjną przy Uniwersytecie Jagiellońskim uzyskał dyplom nauczyciela historii i filologii klasycznej. Ponadto jako magister pedagogiki mógł uczyć przedmiotów pedagogicznych w seminariach nauczycielskich i liceach pedagogicznych ${ }^{18}$. Po ukończeniu studiów pedagogicznych prowadził wykłady na kursie wakacyjnym zorganizowanym przez Ministerstwo Wyznań Religijnych i Oświecenia Publicznego dla nauczycieli szkół powszechnych w Warszawie ${ }^{19}$.

Jeszcze jako student zauważał, że region, z którego pochodził, pomimo posiadanego potencjału ludnościowego i gospodarczego, nie miał własnej uczelni uniwersyteckiej. Już w 1929 r. na łamach „Zarania Śląskiego” zamieścił artykuł postulatywny w sprawie utworzenia w Katowicach uniwersytetu ${ }^{20}$.

W 1931 r. rozpoczął pracę jako nauczyciel Seminarium Nauczycielskiego w Cieszynie. Uczył historii, psychologii, dydaktyki, i historii wychowania. W 1932 r. otrzymał bezpłatny urlop w Seminarium. Formalnie na etacie w cieszyńskim Seminarium, a później Liceum Pedagogicznym pozostawał do 1945 r. Jako nauczyciel cieszyńskiej szkoły był od 1931 r. członkiem Związku Nauczycielstwa Polskiego ${ }^{21}$.

W maju 1932 r. wziął udział w kursie zorganizowanym przez Ministerstwo Wyznań Religijnych i Oświecenia Publicznego w Lesznie poświęconym programom przedmiotów pedagogicznych w seminariach i tworzonych liceach pedagogicznych. Jednocześnie pro-

15 W. Błońska, Dokonania organizacyjne i dydaktyczne Prof. dr. hab. Józefa Pietera w instytucjach i szkołach wyższych, [w:] Prof. zw. dr. hab. Józef Pieter. Działalność i dzieła. Materiały posesyjne, s. 67.

16 J. Pieter, Twórczość pedagogiczna Johna Deweya, „Kwartalnik Pedagogiczny” 1931, nr 2, s. 1-64;.

17 J. Pieter, O stopniu zależności inteligencji od warunków środowiskowych, „Chowanna” 1936, nr 4-10, s. 10-15; J. Pieter, Poziom inteligencji a środowisko dzieci śląskich, „Zaranie Śląskie” 1938, nr 2, s. 20-26; W. BobrowskaNowak, op. cit., s. 14.

18 Muzeum w Skoczowie, Dyplom z dnia 06.05.1930 Nauczyciela Szkół Średnich wydany przez Prezydium Państwowej Komisji Egzaminacyjnej dla kandydatów na nauczycieli szkót średnich w Krakowie.

19 W. Błońska, op. cit., s. 67-68

20 J. Pieter, Kilka uwag w sprawie organizacji pracy naukowej na Śląsku, „Zaranie Śląskie” 1929, nr 4, s. 197-215; M. Salamon, Powstanie Uniwersytetu Śląskiego, [w:] Katowice. W 143. Rocznicę uzyskania praw miejskich. W 40-lecie powstania uniwersytetu śląskiego - szkolnictwo i nauka na Górnym Śląsku, red. A. Barciak, Katowice 2009, s. 44.

21 Szerzej patrz: T. Tomoszek, Zarys dziejów Liceum Pedagogicznego w Cieszynie, [w:] Księga pamiątkowa Liceum Pedagogicznego w Cieszynie. Wydana z okazji 50-lecia Męskiego Seminarium Nauczycielskiego i Liceum Pedagogicznego im. Pawła Stalmacha w Cieszynie, red. J. Broda, Cieszyn 1959, s. 40-49. 
wadził ćwiczenia do wykładów prof. Stefana Szumana w Instytucie Pedagogicznym w Katowicach z testów psychologicznych oraz statystyki dla psychologów ${ }^{22}$. W 1933 r. wygłosił cykl wykładów publicznych z psychologii rozwojowej i wychowawczej dla nauczycieli województwa śląskiego ${ }^{23}$.

We wrześniu 1932 r. na podstawie decyzji Rady Wydziału Filozoficznego UJ został starszym asystentem u prof. Szumana w Katedrze Psychologii Pedagogicznej. Prowadził zajęcia ze statystyki i nauki o testach psychologicznych. Zatrudnienie na Uniwersytecie Jagiellońskim wychodziło naprzeciw zainteresowaniom i aspiracjom dr. Pietera. Pozwalało mu na rozwój naukowy, stanowiący dla niego niejako sens życia zawodowego. W tym okresie prowadził badania o charakterze empirycznym, których efektem była praca Psychologia filozoficznego światopoglądu młodzieży, będąca częścią trzyczęściowego dzieła Psychologia światopoglądu młodzieży ${ }^{24}$. Stosunki z prof. Szumanem pogorszyły się po napisaniu przez Pietera nieopublikowanej krytycznej, ale rzeczowej recenzji pracy Stanisława Szumana i Stanisława Skowrona Organizm a życie psychiczne. Jesienią 1933 r. z polecenia prof. Szumana zajął się ponownie badaniami nad testami wiadomości. Efektem badań była książka Nowe sposoby egzaminowania, będąca pierwszym w Polsce psychologicznym wprowadzeniem ogólnym do teorii egzaminów testowych.

Oprócz asystentury na Uniwersytecie Jagiellońskim nadal prowadził zajęcia w Instytucie Pedagogicznym w Katowicach oraz Państwowym Pedagogium w Krakowie. W tym ostatnim miał wykłady z psychologii rozwojowej i wychowawczej na trzech kierunkach studiów: matematyce, polonistyce i przyrodzie. W okresie asystentury na Uniwersytecie Jagiellońskim uczęszczał na zebrania naukowe krakowskiego Stowarzyszenia Neurologów i Psychiatrów. Starał się również uzupełnić wiedzę z budowy i fizjologii układu nerwowego, toteż uczęszczał w tym czasie na wykłady z anatomii i fizjologii układu nerwowego człowieka na Wydziale Medycznym UJ. Wyrobiło się wtedy w nim przekonanie, że wiedza naukowa o ludzkim mózgu jest mało przydatna psychologowi ${ }^{25}$.

W maju 1935 r. złożył podanie o stypendium do Funduszu Kultury Narodowej26. Po jego otrzymaniu otrzymał bezpłatny półroczny urlop na studia za granicą od 1 września 1935 r. do 28 lutego 1936 r. Jednocześnie został zmuszony do złożenia deklaracji rezygnacji z asystentury na UJ z końcem roku akademickiego 1935/193627. Trasa jego naukowego wojażu wiodła przez najważniejsze europejskie ośrodki akademickie zajmujące się problemami psychologii człowieka: Wiedeń, Zurych, Paryż oraz Londyn ${ }^{28}$. Podczas wyjazdu zagranicznego nawiązał kontakty naukowe z czołowymi wówczas psychologami i pedagogami europejskimi ${ }^{29}$. Docelowym celem podróży był Londyn, gdzie czas spędzał głównie w Bibliotece British Muzeum. Studiował tam literaturę etnopsychologiczną i etnograficzną. Zapoznał się z nowościami z psychologii rozwojowej, psychologii mowy i antropologii kulturowej.

24 J. Pieter, Psychologia filozoficznego światopoglądu młodzieży, [w:] S. Szuman, J. Pieter, H. Weryński, Psychologia światopoglądu młodzieży, Kraków 1933, s. 211-385; W. Błońska, op. cit., s. 68; Pieter Józef, prof. dr. hab. (biogram), s. 282.

25 J. Pieter, Czasy i ludzie, t. 1, s. 268-269.

26 J. Pieter, Czasy i ludzie, t. 3, Toruń 1997, s. 297.

27 J. Pieter, Czasy i ludzie, t. 1, s. 273-275.

28 E. Pieter-Kania, op. cit., s. 9.

29 W. Błońska, op. cit., s. 68; J. Pieter, Czasy i ludzie, t. 2, Toruń 1997, s. 477. 
Po powrocie otrzymał propozycję pracy w Centralnym Instytucie Wychowania Fizycznego w Warszawie. Z dniem 1 września 1936 r. został tam starszym asystentem u prof. Stefana Baleya. W CIWF Pieter jako jedyny stały asystent posiadał znaczną samodzielność nie tylko badawczą - badań eksperymentalnych - lecz również w kwestii organizacji Zakładu Psychologii Sportu30. W początkowym okresie pobytu w CIWF dużo czasu poświęcił na zapoznanie się dość bogatą literaturą z psychologii wojskowej, psychologii sportu i psychomotoryce. Jednocześnie prowadził dodatkowe wykłady w: Studium Wojskowym, Podchorążówce Marynarki Wojennej w Toruniu (od 1939 r. w Bydgoszczy) oraz był doradcą w Sekcji Psychotechnicznej Departamentu Dowodzenia Ogólnego Ministerstwa Spraw Wojskowych ${ }^{31}$. Doraźnie dawał wykłady dla wojskowych w Centralnym Kasynie Oficerskim w Warszawie ${ }^{32}$. Od 1936 r. prowadził wykłady z psychologii na kursie wakacyjnym we Lwowie zorganizowanym przez warszawski Instytut Pedagogiczny Związku Nauczycielstwa Polskiego. Nadal wykładał w Instytucie Pedagogicznym w Katowicach.

Praca w CIWF oznaczała stabilizację finansową. Dlatego zdecydował się na założenie rodziny. W 1936 r. poślubił Aldonę Herwy ${ }^{33}$. Żona okazała się wierną towarzyszką życia i bardzo dobrą gospodynią, dbającą o rodzinę. Zrezygnowała z kariery zawodowej na rzecz rodziny. Dzięki żonie Pieter mógł w dużym stopniu kontynuować bez większych przeszkód działalność naukową. We wrześniu 1938 r. urodził się ich syn Jacek.

W tym czasie prowadził badania terenowe w 30 miejscowościach ówczesnego województwa śląskiego. Ich wyniki opublikował na łamach „Chowanny” w 1936 r. ${ }^{34}$ Szczególnie dużo czasu poświęcił badaniom strachu u dzieci szkolnych. Podjął również badania nad wpływem środowiska społecznego na rozwój intelektualny ucznia. Szczególne znaczenie przypisywał poszerzaniu potrzeb kulturalno-oświatowych w poszczególnych środowiskach, głównie domowym, pozaszkolnym i szkolnym. W konsekwencji opublikował przewodnik metodyczny ${ }^{35}$. Zajmował się również „problemami filozofii i kultury fizycznej odniesionymi do historii tej nauki i jej aspektów psychologicznych" ${ }^{36}$. Od jesieni 1937 r. rozpoczął badania nad uzdolnieniami psychometrycznymi. W związku z rozpoczęciem procedury habilitacyjnej na Uniwersytecie Poznańskim otrzymał propozycję zatrudnienia na stanowisku docenta w Wolnej Wszechnicy Polskiej w Warszawie. Od jesieni 1939 r. miał objąć etat psychologa w Centrum Badań Lotniczych w Warszawie. W 1939 r. opublikował pracę habilitacyjną z psychologii, ale wybuch wojny pokrzyżował jego plany.

Znając nastawienie niemieckiego okupanta do polskiej inteligencji, Józef Pieter od początku czuł zagrożenie dla życia. Krótko pracował fizycznie przy odbudowie budynków

30 J. Pieter, Czasy i ludzie, t. I, s. 300; Pieter Józef, prof. dr. hab. (biogram), s. 282.

31 Tamże.

32 J. Pieter, Czasy i ludzie, t. I, s. 310-313.

33 Muzeum w Skoczowie, Dokument ślubu Aldony Herwy i Józefa Pietera z dnia 02.01.1937; Świadectwo ślubu kościelnego zawartego 03.01.1937.

34 W. Bobrowska-Nowak, op.cit., s. 14

35 J. Pieter, Przewodnik metodyczny do analizy warunków środowiska wychowawczego dzieci szkolnych. Badania psychologiczne nad dziećmi śląskimi, „Chowanna” 1934, nr 6-7, s. 21-45; idem, Poziom inteligencji a środowisko dzieci śląskich, „Zaranie Śląskie” 1938, nr 2, s. 3-20; idem, Badania nad czynnikami warunkującymi zróżnicowanie ilorazów inteligencji dzieci i młodzieży , „Polskie Archiwum Psychologii” 1938, s. 81-102.

36 W. Bobrowska-Nowak, op. cit., s. 18; J. Pieter, Pochodzenie filozofii a sprawa kultury fizycznej, „Ruch Pedagogiczny" 1938-1939, nr 8, 9, 10, s. 8-20; J. Pieter, O pochodzeniu filozofii, „Przegląd Filozoficzny” 1939, s. 1-64. 
CIWF, a później w firmie szklarskiej ${ }^{37}$. Pod koniec stycznia 1940 r. znalazł zatrudnienie jako prywatny nauczyciel w ziemiańskim dworze Wodzińskich w Zaborówku koło Warszawy. Uczył wszystkich przedmiotów z programu licealnego. Przygotowywał swoich uczniów do zdawania egzaminów zaliczeniowych na tajnych kompletach ${ }^{38}$. Pod koniec maja $1941 \mathrm{r}$. zdecydował się na wypowiedzenie umowy Wodzińskim, a tym samym rezygnację z „posady". Spowodowane to było złamaniem przez nich warunków umowy.

Rezygnacja z pracy w Zaborówku znacznie pogorszyła sytuację ekonomiczną rodziny Pieterów. Krótkotrwałe zatrudnienie w warszawskich fabryczkach przynosiło znikome dochody. Krótko pracował w biurze personalnym niemieckiej fabryki na Pradze - Mechanische Werkstätten Neubrandenburg ${ }^{39}$ oraz jako biuralista w Fabryce Farb i Lakierów Kraussego $^{40}$. Praca ta obok bardzo małego wynagrodzenia dawała mu jednak dokumenty zabezpieczające przed przypadkowym aresztowaniem, a zwłaszcza wywiezieniem na przymusowe roboty do Niemiec. W związku ze zbliżającymi się narodzinami drugiego dziecka - córki Ewy - zdecydował się na wyjazd z Warszawy wraz z rodziną. Pod koniec sierpnia 1942 r. przeniósł się do Krakowa, gdzie podjął pracę jako tłumacz w firmie Handwerkeverlag A.G. Krakau, która wydawała w języku polskim dwutygodnik „Rzemiosło"41. W 1943 r. był zmuszony zrezygnować z pracy w wydawnictwie. Był to skutek drobnego w zasadzie zatargu z jednym z niemieckich pracowników firmy, który zaczął mu grozić wysłaniem do obozu Auschwitz ${ }^{42}$. W trudnych czasach okupacji rodzina była dla niego niejako sensem życia. Każdą wolna chwilę od pracy poświęcał najbliższym ${ }^{43}$.

Jesienią 1942 r. za pośrednictwem dr. Stanisława Kuśnierza rozpoczął współpracę z konspiracyjnym Kuratorium Śląskim w Krakowie ${ }^{44}$, które prowadziło działania mające na celu przygotowanie kadr, programów nauczania oraz zasad nauczania po wyzwoleniu Śląska spod okupacji niemieckiej. Kuratorium widziało w nim jednego z tych, którzy w przyszłości, po wyzwoleniu będą odbudowywali polską oświatę na Górnym śląsku. Wiosną 1944 r. zdecydował się na wyjazd z Krakowa. Osiadł w Czernichowie pod Krakowem, gdzie podjął przerwane badania naukowe ${ }^{45}$. Celem było swoiste scalenie badań nad formami życia ludzkiego, do tej pory mieszczącymi się nie tylko w obszarze psychologii, lecz również ekonomii, medycyny czy prawa. Przygotowane opracowanie zawierało problematykę: walki o byt, życia seksualno-erotycznego, rodzinnego, życia towarzyskiego, zabawowego, kulturalnego oraz taktykę współdziałania i konfliktów z innymi ludźmi ${ }^{46}$. Zatytułował je Biografia ogólna" Została ona opublikowana w 1946 r. Podstawowym założeniem przyjętym w tej pracy było stwierdzenie, że „człowiek jest ciągle jeszcze istotą nieznaną". Przyczynę takiegoż stanu rzeczy widział w wadliwym ujęciu problematyki pedagogiczno-psychologicznej. Biografia ogólna miałaby w wielu sytuacjach zastępować

Muzeum w Skoczowie, Zaświadczenie właściciela Warsztatu Szklarskiego w Warszawie z dnia 20.09.1940 o zatrudnieniu J. Pietera.

38 Pieter Józef, prof. dr. hab. (biogram), s. 282.

39 Przedwojenne zakłady „Avia”

40 J. Pieter, Czasy i ludzie, t. 2, s. 91-108.

41 Ibid., s. 115. Później firma nosiła nazwę Verlag für Wirstschaft und Handwerk.

42 J. Pieter, Czasy i ludzie, t. 3, s. 31.

43 Ibid., s. 84.

44 Pieter Józef, prof. dr. hab. (biogram), s. 282.

45 Muzeum w Skoczowie, Policyjne zameldowanie z dnia 12.06.1944 po przeprowadzce z Krakowa do Czernichowa.

46 J. Pieter, Czasy i ludzie, t. 1, s. 6. 
psychologię, zwłaszcza psychologię społeczną, której Pieter zarzucał zbytnią abstrakcyjność i nieliczenie się z realnymi strukturami życia psychicznego. Postulował stworzenie nowej dziedziny nauki - „techniki moralnej”, czyli zastosowania odpowiedniej wiedzy humanistycznej. Taka technika powinna być oparta na ścisłych wynikach badań. Wiedza humanistyczna jego zdaniem powinna być ścisła. Dla dr. Pietera ścisłość była warunkiem prawdziwej naukowości. Ścisłość oznaczała dla niego głównie eksperymentalny charakter nauki i oparcie biografii ogólnej na eksperymentach. Jego zdaniem eksperymentowanie jest możliwe, ponieważ „władza” systematycznie wtrąca się w sferę wolności i osobowości, „czemuż nie mógłby biograf wtrącać się w nią w imię polepszenia i zharmonizowania współżycia między ludźmi". Pokłosiem rozmyślań czernichowskich były ponadto Problemy cywilizacji technicznej oraz Wychowanie ludzi uspołecznionych. Podczas pobytu w Czernichowie podjął również pracę nad Słownikiem psychologicznym.

Po wyzwoleniu w połowie lutego 1945 r. dr Pieter udał się do Krakowa ${ }^{47}$, gdzie w porozumieniu z prof. Władysławem Heinrichem objął stanowisko starszego asystenta w Katedrze Psychotechnicznej UJ. W połowie tegoż miesiąca został ponadto mianowany kierownikiem Pracowni Psychotechnicznej przy Muzeum Przemysłowym w Krakowie. W połowie marca zdecydował się jednak na rezygnację z pracy w krakowskich instytucjach, by związać się z Górnym Śląskiem, gdzie został mianowany p.o. dyrektora i organizatorem reaktywowanego Instytutu Pedagogicznego w Katowicach $^{48}$. Jednocześnie otrzymał nominację na dyrektora organizowanego Pedagogium Państwowego w Bytomiu ${ }^{49}$. W pierwszym okresie kierowania Instytutem skupił się na zabezpieczeniu bazy lokalowej, zdobywaniu funduszy, rewindykacji majątku przedwojennego Instytutu oraz rekrutacji kadry nauczającej i słuchaczy przedwojennych, którzy nie ukończyli studiów celem złożenia przez nich egzaminów końcowych. Dzięki osobistym zabiegom zaczął gromadzić kadrę naukową, głównie z Krakowa ${ }^{50}$. Wiosną 1945 r. z jego inicjatywy przy Instytucie zorganizowano Poradnię Psychologiczno-Pedagogiczną. Jako dyrektor Instytutu powołał w 1947 r. dwuletnie Wyższe Studium Wychowania Przedszkolnego.

Jednocześnie z organizowaniem Instytutu podjął starania mające na celu odtworzenie jego pozadydaktycznych form - czasopisma oraz poradni psychologicznej i wychowawczej. Skutkiem tego reaktywowano czasopismo pedagogiczne „Chowanna”. Zorganizował wspomnianą poradnię pedagogiczną oraz rozpoczął wydawanie pozycji z zakresu pedagogiki w ramach „Biblioteki Nauczyciela”. Pod redakcją Józefa Pietera ukazała się w tym czasie pierwsza w Polsce powojenna encyklopedia przyrodnicza: Obraz syntetyczny współczesnej wiedzy przyrodniczej ${ }^{51}$. W 1948 r. objął funkcję redaktora „Ruchu Pedagogicznego". Wiosną 1946 r. wszedł w skład zarządu Instytutu Śląskiego oraz Śląsko-Dąbrowskiego Towarzystwa Przyjaciół Nauk.

47 Muzeum w Skoczowie, Policyjne wymeldowanie z Czernichowa z dnia 20.02.1945.

48 Pieter Józef, prof. dr. hab. (biogram), s. 282.

49 J. Pieter, Pierwsza wyższa uczelnia polska na Śląsku, „Zaranie Śląskie” 1957, z. 1-2, s. 42-54.

50 Szerzej patrz: Cz. Głombik, Obecność filozofa. Studia historycznofilozoficzne o Władysławie Tatarkiewiczu, Katowice 2005.

51 W ramach serii „Świat-Życie-Człowiek”. 
Po wyzwoleniu wrócił do idei powstania uniwersytetu na Górnym Śląsku ${ }^{52}$. Współtworzył Obywatelski Komitet Przygotowawczy Uniwersytetu Śląskiego, formalnie powołany w Katowicach 5 maja 1945 r., który był jednym z głównych propagatorów powołania uniwersytetu w tym regionie. 22 maja Komitet ogłosił Memoriał w sprawie założenia uniwersytetu w województwie śląsko-dąbrowskim ${ }^{53}$. Postulowano pozyskanie dla uniwersytetu kadry naukowej z byłego polskiego Uniwersytetu Stefana Batorego we Lwowie. Uczelnia miała kształcić nauczycieli szkół średnich, lekarzy i prawników głównie spośród miejscowej ludności. Do memoriału były załączone aneksy, m.in. autorstwa dr. Pietera, w których wyliczano argumenty przemawiające za umieszczeniem uczelni na terenie okręgu przemysłowego na Górnym Śląsku: potencjał ludnościowy, względy społeczne (umożliwienie dostępu robotników do wykształcenia uniwersyteckiego), korzystne warunki komunikacyjne, tradycję funkcjonowania przedwojennego Instytutu Pedagogicznego ${ }^{54}$. Sprawa jednak upadła na skutek negatywnego stanowiska władz centralnych ${ }^{55}$.

We wrześniu 1945 r. dr Pieter zwrócił się do Wydziału Filozoficznego Uniwersytetu Poznańskiego z prośbą o wznowienie przerwanego przez wybuch wojny przewodu habilitacyjnego. Za pracę habilitacyjną uznano opublikowaną w 1939 r. w języku angielskim pracę Inteligence Quotient and Environment, będącą syntezą badań nad korelacją poziomu inteligencji z warunkami środowiska wychowawczego uczniów szkół powszechnych na polskim Śląsku w wieku 11-14 lat. Kolokwium odbyło się 18 listopada 1945 r. ${ }^{56}$

W czerwcu 1946 r. Ministerstwo Oświaty powierzyło mu zorganizowanie w Katowicach Państwowej Wyższej Szkoły Pedagogicznej. Powołało Komisję Organizacyjną Wyższej Szkoły Pedagogicznej. W sierpniu tegoż roku doc. Pieter dostał nominację na p.o. dyrektora PWSP w Katowicach, która rozpoczęła działalność 1 października 1946 r. $^{57}$ Jednakże z powodu trudności lokalowych we wrześniu 1947 r. katowicka PWSP została połączona z PWSP w Łodzi ${ }^{58}$.

Po uzyskaniu habilitacji otrzymał propozycje pracy z wielu ośrodków akademickich w Polsce, jednakże uczelnie te nie były mu w stanie zapewnić mu mieszkania, a dojazdy były $z$ reguły zbyt czasochłonne, dlatego był zmuszony je odrzucić. W tym okresie rozważał również możliwość oparcia zarobkowania tylko na pisaniu artykułów i książek z dziedziny psychologii i pedagogiki. W pierwszych latach powojennych zdawało się to zupełnie realne. Jednakże na przełomie lat 1947/1948 możliwości zarobkowania „piórem" praktycznie zniknęły. Był to efekt z jednej strony likwidacji wydawnictw prywatnych,

52 Pismo dyrektora Wyższego Studium Nauk Społeczno-Gospodarczych w Katowicach dr Józef Liska do wojewody śląsko-dąbrowskiego gen. dyw. Aleksandra Zawadzkiego w sprawie utworzenia uniwersytetu śląskiego, [w:] Wyrósł z dobrego drzewa. Uniwersytet Śląski 1968-1998. Fakty, dokumenty, relacje, Katowice 1998, s. 195-197.

53 Memoriał w sprawie założenia Uniwersytetu w województwie śląsko-dąbrowskim, Katowice 1945, s. 3-6; A. Czech, Starania o uniwersytet w Katowicach w 1945 roku, [w:] Prof. zw. dr. hab. Józef Pieter. Działalnośc i dzieła. Materiały posesyjne, s. 115-116.

54 Memoriał w sprawie założenia Uniwersytetu w województwie śląsko-dąbrowskim, s. 2-27.

55 W. Błońska, op. cit., s. 70; S. Fertacz, Na drodze do uniwersytetu, s. 39.

56 Muzeum w Skoczowie, Pismo ministra Oświaty z dnia 17.09.1946 o zatwierdzeniu uchwały o habilitowaniu na docenta psychologii Rady Wydziału Humanistycznego Uniwersytetu Poznańskiego w Poznaniu z dnia 18.11.1945 popartej przez Senat Akademicki w dniu 21.12.1945.

57 Muzeum w Skoczowie, Kopia pisma ministra Oświaty Rzeczpospolitej Polskiej z dnia 01.06.1946 o powołaniu na przewodniczącego Komisji Organizacyjnej Wyższej Szkoły Pedagogicznej w Katowicach; Zaświadczenie z dnia 18.11.1946 PWSPW Katowicach o zatrudnieniu w charakterze dyrektora dr J. Pietera.

58 E. Pieter-Kania, op. cit., s. 10; W. Błońska, op. cit., s. 70. 
a z drugiej nasilającej się cenzury, blokującej wszelkie treści niepropagujące nowej rzeczywistości59. Skutkiem tego było zdanie się na działalność dydaktyczną jako podstawę uzyskiwania środków utrzymania. Stał się jednym z profesorów „na kółkach”, czyli mających wykłady na kilku uczelniach lub innych instytucjach oświatowych. Jesienią 1948 r. przyszły kolejne propozycje z Uniwersytetów Poznańskiego i Warszawskiego objęcia katedr pedagogiki eksperymentalnej. Szczególne nadzieje wiązał z Uniwersytetem Warszawskim, gdzie prof. Bogdan Suchodolski półoficjalnie zaproponował mu objęcie katedry pedagogiki eksperymentalnej. Liczył na połączenie etatu na Uniwersytecie z Akademią Wychowania Fizycznego, powstałą na bazie przedwojennego CIWF. Wahał się nad przyjęciem tej propozycji, kiedy Rada Wydziału Uniwersytetu Łódzkiego uzyskała zgodę na stworzenie Katedry Psychologii Rozwojowej i zaproponowała mu jej kierownictwo jako profesorowi nadzwyczajnemu ${ }^{60}$. W konsekwencji przyjął proponowane stanowisko w lutym $1949 \mathrm{r}^{61}$ Oficjalną nominację na profesora nadzwyczajnego otrzymał 16 maja 1949 r. ${ }^{62}$ Jednocześnie na podstawie porozumienia z Zarządem Głównym ZNP miał nadal kierować Instytutem Pedagogicznym w Katowicach. Oprócz zajęć na Uniwersytecie prowadził wykłady na Kursie Pedagogicznym Ministerstwa Oświaty. W 1950 r. był zmuszony dawać wykłady na nowo zorganizowanym w ramach Uniwersytetu Łódzkiego Studium Nauk Społecznych. W lipcu 1950 r. w związku z likwidacją Instytutu Pedagogicznego w Katowicach został odwołany ze stanowiska dyrektora63.

W marcu 1951 r., po wizytacji jego zajęć przez przedstawicieli Kongresu Nauki Polskiej, zarzucono mu, że nie zna pedagogiki i psychologii radzieckiej oraz że plan prac magisterskich nie został oparty na założeniach materializmu dialektycznego i historycznego ${ }^{64}$. Sytuacja dla prof. Pietera stała się bardzo groźna. Odstawał w swoich poglądach i nauczaniu od linii narzuconej przez partię i władze komunistyczne. Z kolei w czasie spotkania ludzi związanych z naukami pedagogicznymi w grudniu 1952 r. w Rogowie koło Koluszek w czasie dyskusji zarzucono mu, że jego prace nie mają nic wspólnego z marksizmem. Nakłaniano go do złożenia samokrytyki, zmiany poglądów na marksistowskie oraz podjęcia badań na „bazie światopoglądu naukowego”65. Prof. Pieter był zwłaszcza krytycznie nastawiony wobec teorii Pawłowa, któremu zarzucał swoistą „zachłanność naukową”. Nie zgadzał się z możliwościami zastosowania pawłowizmu jako uniwersalnego środka do badań nad psychologią człowieka.

W 1952 r., po reorganizacji katedr na Uniwersytecie Łódzkim prof. Pieterowi powierzono kierownictwo katedry psychologii. Krótko po tym, z obawy przed likwidacją w przyszłości katedry psychologii, zdecydował się na szukanie nowego miejsca zatrudnienia. Ostatecznie od listopada 1953 r. podjął pracę na Uniwersytecie Warszawskim. Prowadził wykłady z psychologii rozwojowej oraz psychologii wychowawczej. Ponadto prowadził seminarium magisterskie, na którym skupił się na efektywności korzystania z lektur w pra-

59 J. Pieter, Czasy i ludzie, t. 3, s. 85.

60 Muzeum w Skoczowie, Oświadczenie z dnia 15.03.1948 o zgodzie na objecie katedry profesora pedagogiki i organizacji szkolnictwa na Uniwersytecie tódzkim.

61 Pieter Józef, prof. dr. hab. (biogram), s. 282.

62 Muzeum w Skoczowie, Nominacja na profesora nadzwyczajnego z dnia 16.05.1949 podpisana przez prezydenta B. Bieruta; Pieter Józef, prof. dr. hab. (biogram), s. 282.

63 S. Fertacz, Na drodze do Uniwersytetu, s. 43.

64 J. Pieter, Czasy i ludzie, t. 2, s. 308-309.

65 Ibid., s. 313-314. 
cy szkolnej oraz przygotowaniu się uczniów do szkoły. Podobnie jak w Łodzi, w Warszawie wśród studentów trafiali się aktywiści partyjni lub ZMP-owcy, którzy niejednokrotnie stawiali prowokacyjne pytania, starając się go przyłapać na braku „prawomyślności”.

W tym czasie ponownie znalazł drugi etat na warszawskiej Akademii Wychowania Fizycznego. Uzyskał tam własną katedrę psychologii. Prowadził wykłady z psychologii ogólnej i wychowawczej. Posiadał tam również większą samodzielność naukową, gdyż psychologia była przedmiotem drugorzędnym i nie kładziono takiego nacisku na pawłowizm. Dobrze zapowiadająca się działalność naukowa w ramach Akademii Wychowania Fizycznego została jednak przerwana z powodu konfliktu z władzami uczelni na tle przydziału mieszkania w Warszawie. W tej sytuacji prof. Pieter poczuł się urażony i zdecydował się na rezygnację z etatu po zakończeniu roku akademickiego 1955/1956. Nadal jednak występował jako konsultant oraz recenzent prac dyplomowych na AWF'66.

Udzielał się również w pracach Polskiej Akademii Nauk. Aktywnie zaangażował się w przygotowanie konferencji organizowanej wspólnie przez Instytut Pedagogiki Ministerstwa Oświaty ${ }^{67}$ i Komitet Pedagogiczny PAN, dotyczącej programów nauczania w szkołach ogólnokształcących. Pomimo związania się z Łodzią, a następnie Warszawą nie rezygnował z pracy dydaktycznej na Górnym Śląsku. Od 1950 r., po zorganizowaniu w Katowicach nowej Państwowej Wyższej Szkoły Pedagogicznej był jej wykładowcą jako profesor nadzwyczajny na godzinach zleconych ${ }^{68}$.

Dojazdy do Warszawy stawały się jednak coraz bardziej męczące, na dodatek odbiły się na jego stanie zdrowia. Cierpiał na przeziębienia oraz reumatyzm. To oraz brak perspektyw otrzymania mieszkania w Warszawie zadecydowały o podjęciu decyzji o zerwaniu nie tylko z AWF, lecz również Uniwersytetem Warszawskim ${ }^{69}$.

Niespodziewanie dla prof. Pietera grupa pracowników PWSP w Katowicach, na czele z chemikiem dr. Tadeuszem Dobrowolskim, wysunęła jego kandydaturę na stanowisko rektora, argumentując, że: był jedynym stałym profesorem akademickim zatrudnionym w PWSP, posiadał doświadczenie jako były dyrektor Instytutu Pedagogicznego w Katowicach, nie ugiął się w czasach stalinizmu, cieszył się zaufaniem pracowników PWSP oraz dawał gwarancję rozwoju PWSP jako szkoły akademickiej, a nawet przekształcenia jej w uniwersytet ${ }^{70}$.

Ostatecznie 23 października 1956 r. jednomyślnie został wybrany rektorem Wyższej Szkoły Pedagogicznej w Katowicach ${ }^{71}$. Po objęciu funkcji rektora prof. Pieter dążył do podniesienia prestiżu powierzonej mu szkoły wyższej. Temu celowi służyło m.in. nawiązanie bliższej współpracy wszystkich uczelni na terenie ówczesnego województwa katowickiego: Akademii Medycznej, Politechniki Śląskiej, Politechniki Częstochowskiej, Wyższej Szkoły Ekonomicznej, Wyższej Szkoły Muzycznej, Wyższej Szkoły Sztuk Plastycznych oraz Wyższej Szkoły Pedagogicznej. Został organizatorem i przewodniczącym Komisji Pedago-

66 Ibid., s. 339-341.

67 Instytut Pedagogiki powstał w miejsce Ośrodka Badań Programowych i Metodycznych Ministerstwa Oświaty.

68 Rozporządzenie Rady Ministrów w sprawie Utworzenia Państwowej Wyższej Szkoły Pedagogicznej w Katowicach, "Dziennik Ustaw” nr 55, 1955, poz. 498.

69 Archiwum Uniwersytetu Śląskiego w Katowicach [dalej: Archiwum UŚ], Kronika PWSP w Stalinogrodzie 19501953, Pierwsze władze PWSP w Katowicach, bez paginacji.

70 J. Pieter, Czasy i ludzie, t. 2, s. 351; t. 3, s. 363.

71 Archiwum UŚ, Kronika WSP 1956-1962, Informacja o wyborze nowych władz w PWSP, bez paginacji. 
gicznej Śląskiego Instytutu Naukowego w Katowicach. Bliską współpracę nawiązał z Politechniką Śląską. Jako rektor WSP skupił się głównie na jej rozwoju kadrowym i naukowym. W latach 1959-1963 był przewodniczącym Zespół Rzeczoznawców do Przedmiotów Pedagogicznych istniejącym przy Ministerstwie Oświaty ${ }^{72}$. Zespół opracował ramowe programy studiów pedagogicznych na specjalizacjach: pedagogika szkolna, nadzór pedagogiczny, opiekuństwo wychowawcze oraz pedagogika rehabilitacyjna ${ }^{73}$.

Zdając sobie sprawę z niedowartościowania nauk humanistycznych, prof. Pieter doprowadził do otwarcia nowych kierunków studiów na WSP: pedagogiki, historii, psychologii, socjologii, wychowania technicznego oraz do wydzielenia z filologii polskiej bibliotekoznawstwa. Poza tym chciał uruchomić studia biologiczne i geograficzne. Powołał Komitet Redakcyjny Wydawnictw WSP. W listopadzie 1956 r. opracował plan redakcyjny oraz profil wznowionego kolejny raz czasopisma "Chowanna”. Informowało ono o problemach związanych z wychowaniem, organizacją szkolnictwa i oświatą dorosłych. Jednocześnie miało za zadanie dokształcanie nauczycieli. W 1959 r. jako pierwszy w Polsce opublikował opracowanie poświęcone dziejom psychologii, zatytułowane Historia psychologii w zarysie ${ }^{74}$.

Zamiarem prof. Pietera było przekształcenie typowo wyższej szkoły zawodowej, jaką była katowicka WSP, w szkołę akademicką, a docelowo w uniwersytet. W styczniu 1957 r. opublikował artykuł Kiedy Uniwersytet w Katowicach, w którym postulował jego utworzenie na bazie WSP. Stwierdzał m.in., że trzymilionowa aglomeracja powinna mieć własny uniwersytet ${ }^{75}$. W kwietniu 1958 r. przygotował szczegółowy plan organizacyjny uniwersytetu. Znalazły się w nim również propozycje obsady kadrowej.

W pierwszych latach pełnienia funkcji rektora dla prof. Pietera priorytetem stało się podwyższenie kwalifikacji kadry, głównie poprzez awanse naukowe, oraz pozyskanie pracowników z innych ośrodków naukowych. Dzięki awansom własnych specjalistów i zatrudnianiu na drugim etacie naukowców z innych ośrodków akademickich kadra WSP była porównywalna z uniwersytetami. Prof. Pieter szczególnie intensywnie zabiegał o uzyskanie dla kierowanej przez siebie uczelni praw do doktoryzowania. Udało się to w 1962 r. Jako pierwszy takie prawa uzyskał Wydział Filologiczno-Historyczny ${ }^{76}$, a nieco później w 1963 r., Wydział Matematyki, Fizyki i Chemii ${ }^{77}$. W tym samym czasie uruchomiono studia doktoranckie. Zabiegi prof. Pietera o jak najlepszą obsadę uczelni po kilku latach zaczęły przynosić efekty. W roku akademickim 1965/1966 zatrudnionych było w niej na etatach 31 profesorów i docentów ${ }^{78}$. Dzięki posiadanym prawom do nadawania stopni doktora uczelnia mogła się pochwalić kadrą wywodzącą się w dużym stopniu z własnego środowiska.

72 Muzeum w Skoczowie, Zawiadomienie z dnia 30.03.1957 o powołaniu na członka Zespołu Rzeczoznawców Psychologii w Radzie Głównej Szkolnictwa Wyższego; Pismo Ministerstwa Oświaty z dnia 19.04.1963 o powołaniu na członka rzeczoznawców w zakresie pedagogiki i psychologii; Pismo Ministerstwa Oświaty z dnia 23.04.1963 z podziękowaniem za dotychczasową prace na stanowisku Przewodniczącego Zespołu Rzeczoznawców w zakresie pedagogiki i psychologii z jednoczesna prośbą o dalszy udział w pracach zespołu; Muzeum im. Gustawa Morcinka w Skoczowie.

73 Szkoła długich tradycji i rokujących nadziei, „Trybuna Robotnicza” nr 61 z 13 III 1957 r.

74 J. Pieter, Historia psychologii w zarysie, Katowice 1959.

75 Idem, Kiedy Uniwersytet w Katowicach, „Przemiany” nr 6 z 10 II 1957.

76 Archiwum UŚ, Kronika WSP 1956-1962, Uzyskanie przez Wydział Filologiczno-Historyczny WSP praw nadawania stopnia doktora nauk, brak paginacji.

77 M. Dyba, Śląskie Fundacje Szkół Wyższych, [w:] Wyrósł z dobrego drzewa, Katowice 1998, s. 15-16.

78 S. Fertacz, Na drodze do uniwersytetu, s. 45. 
Prof. Pieter obok sprawowania funkcji rektora jednocześnie kierował Katedrą Pedagogiki WSP. Skupił się na zwiększaniu poziomu dydaktyki w szkołach wyższych. Temu służyły m.in. badania prowadzone przez kierowaną przez niego katedrę. Szczególne znaczenie przypisywał metodologii pracy naukowej. Swoje nowatorskie poglądy w tej dziedzinie wyłożył w opublikowanych w 1948 r. pozycjach: Krytyka dzieł twórczych oraz Z badań nad poprawnością prac naukowych ${ }^{79}$. Zwieńczeniem badań były wydane $\mathrm{w}$ latach pięćdziesiątych i sześćdziesiątych Praca naukowa oraz Ogólna metodologia pracy naukowej ${ }^{80}$. Problematyka racjonalizacji nauczania zyskiwała zainteresowanie w innych ośrodkach akademickich. Wiosną 1958 r. prof. Pieter wygłosił cykl wykładów na Politechnice Śląskiej. W konsekwencji jeszcze w tym samym roku zorganizował wspólnie z prof. Marianem Januszem z Politechniki Śląskiej w dniach 9-11 listopada 1958 r. ogólnopolską sesję naukową poświęconą tej problematyce. Rezultatem konferencji była dwutomowa publikacja Dydaktyka szkoły wyższej, wydana wspólnie przez WSP i Politechnikę Śląską ${ }^{81}$. Dzięki sesji WSP osiągnęło pewien prestiż w polskim środowisku naukowym. W grudniu 1961 r. na WSP zorganizowano kolejną konferencję poświęconą tym razem problemom wychowania młodzieży akademickiej. Wzięli w niej udział naukowcy z wszystkich uczelni wyższych znajdujących się na terenie województwa katowickiego oraz goście z całego kraju.

Jako rektor prof. Pieter zyskał stałe poparcie pracowników WSP. Przed wygaśnięciem jego kadencji w 1959 r. i 1962 r. odbyły się kolejne wybory rektora WSP, w których został wybrany na kolejne kadencje ${ }^{82}$. Jego sytuacja była jednak bardziej skomplikowana, niż w czasie pierwszej kadencji. Po wizytacji wiceministra jesienią 1960 r. minister Wacław Tułodziecki zarzucił mu, że w niewystarczającym stopniu dba o ideologiczne wychowanie studentów kierowanej przez siebie placówki. Konsekwencją tego ataku było podanie się prof. Pietera do dymisji z funkcji rektora katowickiej WSP w czasie spotkania w Ministerstwie Oświaty. Oficjalną rezygnację zamierzał złożyć na posiedzeniu senatu WSP. Do tego jednak nie doszło, gdyż wsparcia politycznego udzielił mu ówczesny sekretarz Komitetu Wojewódzkiego PZPR w Katowicach Edward Gierek.

Rok 1956 oznaczał koniec izolacji międzynarodowej polskich naukowców. Odwilż październikowa dawała możliwości współpracy z zagranicznymi ośrodkami naukowymi. W czerwcu 1958 r. prof. Pieter odwiedził Pragę, Brno i Bratysławę. Spotkał się z profesorami psychologii i pedagogiki. Od lutego do kwietnia 1962 r. przebywał jako stypendysta Fundacji Forda w ośrodkach akademickich w USA. W Nowym Jorku spotkał się z naukowcami z Columbia University, New York University i Fordham University. Ponadto odwiedził: Princeton University, Yale University w New Haven, Harvard University w Cambridge. Wziął udział w spotkaniach zorganizowanych przez nowojorskie Biuro Badań Pedagogicznych oraz w Wyższej Szkole Technicznej w Brooklynie, poświęconych wychowaniu technicznemu. Spotkał się również z Polonią, m.in. w Fundacji Kościuszkowskiej w Nowym Jorku³.

79 J. Pieter, Krytyka dzieł twórczych, Katowice 1948; idem, Z badań nad poprawnością prac naukowych, Katowice 1948.

80 Idem, Praca naukowa, Katowice 1957; idem, Ogólna metodologia pracy naukowej, Wrocław 1967.

81 Dydaktyka szkoły wyższej, t. 1-2, Gliwice 1961; E. Pieter-Kania, op. cit., s. 10.

82 Muzeum w Skoczowie, Pismo Komisji Skrutacyjnej Senatu WSP w Katowicach z dnia 02.06.1959 o wyborze na stanowisko rektora.

83 Fundacja Kościuszkowska - amerykańsko-polska instytucja założona w 1925 r. w Nowym Jorku. Zajmuje się wymianą naukową, prowadzi działalność informacyjną i popularyzatorską w zakresie dziejów kultury i nauki polskiej. 
Zdecydował się jednak na skrócenie pobytu w USA i wykorzystanie reszty stypendium w Europie. Udało mu się spotkać m.in. z prof. Franciszką Baumgarten. Efektem wyjazdu były kontakty korespondencyjne m.in. z profesorami Guy Dugasem i J.R. Simonem.

W 1962 r. przeprowadzono procedurę nadania przez Radę Państwa prof. Pieterowi tytułu profesora zwyczajnego, co nastąpiło 30 kwietnia $1962 \mathrm{r}^{84}$

Prof. Pieter cały czas pozostawał niestrudzonym rzecznikiem powołania uniwersytetu w Katowicach, który byłby głównym ośrodkiem nauki kultury na terenie Górnego Śląska. Problem starano się nagłaśniać w mediach, czyniono zabiegi u władz centralnych państwowych i partyjnych. Koncepcja utworzenia uniwersytetu była coraz mocniej popierana przez władze wojewódzkie ${ }^{85}$. W czasie dyskusji nad powołaniem uniwersytetu w Katowicach pojawiały się głosy, że powinien on powstać w oparciu o tamtejszą WSP, a jej rektor wydawał się naturalnym kandydatem na rektora nowej uczelni. W 1965 r. prof. Pieter został członkiem Komitetu d/s Koordynacji Rozbudowy Wyższych Uczelni na terenie województwa katowickiego ${ }^{86}$. Powstanie w 1964 roku Fili UJ w Katowicach w dłuższej perspektywie oznaczało postawienie pod znakiem zapytania istnienie katowickiej WSP. W 1967 r. w Ministerstwie Oświaty i Szkolnictwa Wyższego powstało opracowanie dotyczące perspektyw rozwoju katowickiego ośrodka uniwersyteckiego w latach 1967-1975.

Mała stabilizacja w Polsce w pierwszych latach rządów Władysława Gomółki zaczęła się na dobre załamywać od połowy lat sześćdziesiątych. Miało to oczywiście wpływ również na sytuację w szkolnictwie wyższym. Większość studentów i pracowników wyższych uczelni opowiadało się za liberalizacją życia politycznego oraz poprawą warunków życia. Pierwsze większe protesty społeczne zaczęły się w 1968 r. Od początku związani z nimi byli zarówno studenci, jak i profesorowie wyższych uczelni. W styczniu tegoż roku prof. Pieter jako rektor katowickiej WSP uczestniczył w spotkaniu w gmachu Komitetu Wojewódzkiego PZPR, któremu przewodniczył Edward Gierek. Gierek potępił wystąpienia pisarzy zgrupowanych w Związku Literatów Polskich oraz zwrócił uwagę na niepokoje uwidaczniające się wśród młodzieży akademickiej. Nie odniósł się natomiast do sprawy przyszłości WSP i Fili UJ. Po spotkaniu Pieter w czasie narady z prorektorami L. Tokarzewskim i J. Zarembą zaproponował wystosować memoriał do Wojewódzkiej Rady Narodowej, KW PZPR i Ministerstwa Szkolnictwa Wyższego o zmianę nazwy „Wyższa Szkoła Pedagogiczna” na „Śląska Akademia Pedagogiczna w Katowicach"87. Memoriał ten został przekazany władzom. Jednocześnie negatywnie odnoszono się do koncepcji oparcia budowy uniwersytetu w Katowicach na bazie katowickiej Filii UJ. Jako główny argument wysuwano słabość kadrową Filii. Działania te miały ułatwić powstawanie nowych kierunków, a w dalszej perspektywie doprowadzić do przekształcenia uczelni w Uniwersytet. Pomimo akceptacji projektu przez senat uczelni nie został on zrealizowany na skutek przeciwdziałania KW PZPR. Wiązało się to z planami powołania uniwersytetu przy jednoczesnym wchłonięciu

84 Muzeum w Skoczowie, Pismo z dnia 30.04.1962 Przewodniczącego Rady Państwa o powołaniu na stanowisko profesora zwyczajnego.

85 J. Pieter, Kiedy Uniwersytet w Katowicach; S. Balicki, Dziś Śląsk czeka na Uniwersytet, „Słowo Powszechne” nr 36 z 12 II 1959.

86 Muzeum W Skoczowie, Pismo z dnia 08.02.1965 przewodniczącego Prezydium Wojewódzkiej Rady Narodowej w Katowicach - z powołaniem na członka Komitetu d/s Koordynacji Rozbudowy Wyższych Uczelni na terenie województwa katowickiego.

87 M. Salamon, Powstanie Uniwersytetu Śląskiego, [w:] Katowice. W 143. Rocznicę uzyskania praw miejskich, s. 49 . 
przez nową szkołę wyższą WSP w Katowicach ${ }^{88}$. Prof. Pieter zaniepokojony pogłoskami o zamiarach likwidacji katowickiej WSP, 23 lutego spotkał się z rektorem UJ prof. Mieczysławem Klimaszewskim. Dzień później doszło do spotkania w Katowicach rektora UJ prof. Klimaszewskiego, prorektora ds. Filii prof. Popiołka z Edwardem Gierkiem i Tadeuszem Pyką, w czasie którego uznano za zasadne włączenie WSP do Filii UJ89. Znamienny jest brak udziału w tym spotkaniu rektora WSP prof. Pietera.

Działania te zbiegły się z postępującą radykalizacją młodzieży akademickiej. Wystąpienia studenckie w Katowicach zostały niejako sprowokowane przez władze wojewódzkie, z których polecenia w nocy z 11/12 marca funkcjonariusze Milicji Obywatelskiej przeprowadzili rewizję w akademikach, zamieszkałych głównie przez studentów WSP oraz WSE. Przed budynkiem Fili UJ doszło do wiecu poparcia dla studentów z innych ośrodków akademickich, który zamienił się w manifestację. Podczas niej chciano przekazać rezolucję do władz wojewódzkich PZPR. Manifestacja została jednak brutalnie spacyfikowana. Działania te jeszcze bardziej zaostrzyły napięta atmosferę. 15 marca studenci ułożyli rezolucję do władz, w której potępili działania sił bezpieczeństwa. Kolejne protesty wybuchły 16 marca, a obok studentów wzięli w nich robotnicy ${ }^{90}$.

Konsekwencją tego było praktyczne przejęcie władzy w WSP przez członków Komitetu Uczelnianego PZPR na czele z dr Alicją Glińską (1924-1999), a później mgr. J. Kozyrą. Prof. Pieter obawiał się odwołania ze stanowiska, gdyż podobnie jak wobec rektorów innych uczelni, tak i wobec niego wysuwano zarzuty, że nie panuje nad sytuacją i wykazuje brak „aktywności wychowawczej”91. Wpływ prof. Pietera na protestujących studentów był niewielki, choćby ze względu na fakt, że wydarzenia skupiały się głównie poza WSP, na terenie Filii UJ. Na początku lutego 1968 r. ówczesny I sekretarz KW PZPR w Katowicach, Edward Gierek wystosował pismo do ministra Henryka Jabłońskiego w sprawie kadry naukowej na Górnym Śląsku, w którym zauważał, że na terenie województwa jest zbyt mało osób studiujących.

W kwietniu 1968 r. Sejm zmienił radykalnie ustawę o szkolnictwie wyższym z 1956 r. ${ }^{92}$ W konsekwencji zniesiono ostatnie elementy autonomii szkół wyższych, m.in. wybór rektorów przez senat uczelni i dziekanów przez rady wydziałów. Rektorów, prorektorów, dziekanów i prodziekanów miał odtąd mianować minister szkolnictwa wyższego. Rektorzy otrzymali, kosztem senatu, znacznie większe kompetencje w zarzadzaniu uczelnią. Nie przyznano im jednak prawa samodzielnego wnioskowania o przyznanie docentury bez porozumienia z senatem. Prof. Pieter stając na stanowisku przestrzegania prawa, odmówił zatwierdzenia listy zaproponowanej przez Komitet Uczelniany PZPR, przedstawionej przez sekretarza Komitetu, mgr. Kozyrę. Pomimo odmowy prof. Pietera pod jego nieobecność listę kandydatów podpisał prorektor Tokarzewski ${ }^{93}$.

88 W. Błońska, op. cit., s. 71.

89 Informacja na temat spotkania rektora UJ prof. Klimaszewskiego z Edwardem Gierkiem 24 lutego 1968, [w:] Wyrósł z dobrego drzewa, s. 272-273.

90 J. Krzyk, Śląska woda gruchotała kości. Marzec 1968 w relacjach świadka i „Trybuny Robotniczej”, "Gazeta Wyborcza" z 16 III 1996; A. Drogoń, Życie społeczne i polityczne Uczelni - rys historyczny, [w:] Mądrość zbudowała sobie dom..., s. 217-219.

91 J. Pieter, Czasy i ludzie, t. 2, s. 438-439.

92 Ustawa z dnia 20 grudnia 1968 r. o zmianie ustawy o szkolnictwie wyższym, Dz.U. 1968, nr 46, poz. 334

93 Wanda Bobrowska-Nowak (1925-2003), polski pedagog i historyk wychowania. Profesor Uniwersytetu Śląskiego. 
W tym samym czasie w Wydziale Nauki i Oświaty Komitetu Wojewódzkiego PZPR w Katowicach powstał projekt połączenia katowickiej Filii UJ z WSP94. Pod koniec maja oficjalnie poinformowano rektora UJ o planowanym oderwaniu od krakowskiej uczelni katowickiej Filii oraz o utworzeniu Uniwersytetu Śląskiego z połączonej Filii UJ i WSP. Poinformowano o tym jednak drugiej zaineresowanej strony, czyli władz WSP. Uniwersytet Śląski w Katowicach formalnie został powołany 8 czerwca 1968 r ${ }^{95}$ Informacja o tym dotarła do prof. Pietera dopiero w połowie czerwca.

Rozpoczął się proces likwidacji WSP. Na ostatnim posiedzeniu senatu uczelni prof. Pieter podziękował obecnym za długoletnią współpracę ${ }^{96}$. Rektorem nowo powstałego Uniwersytetu Śląskiego został 2 lipca 1968 r. prof. Kazimierz Popiołek, dotychczasowy prorektor ds. katowickiej Filii UJ97. Niepowierzenie tej funkcji prof. Pieterowi było skutkiem jego postawy w czasie protestów społecznych wiosna 1968 r. oraz brakiem dyspozycyjności wobec PZPR. Występowała przeciwko niemu zwłaszcza Służba Bezpieczeństwa, zarzucająca mu bezczynność ${ }^{98}$ Prof. Pieter nie był również członkiem PZPR. Inauguracja roku akademickiego na nowo powstałym Uniwersytecie Śląskim miała miejsce 1 października 1968 r. Wśród zaproszonych gości był prof. Pieter. Nie przewidziano jednak dla niego miejsca przy stole prezydialnym ${ }^{99}$. Zaczął się okres swoistego kierowania go na „boczny tor" na nowej uczelni.

Po powstaniu Uniwersytetu Śląskiego prof. Pieter objął funkcję kierownika Katedry Pedagogiki oraz współtworzącego go Zakładu Psychologii. Następnie 26 czerwca 1969 r., po likwidacji katedr, powierzono mu stanowisko dyrektora Instytutu Pedagogiki i Psychologii, wchodzącego w skład Wydziału Humanistycznego ${ }^{100}$. Prof. Pieter zajął się m.in. uruchomieniem studiów psychologicznych na Uniwersytecie Śląskim pomimo wyrażanych wcześniej obaw związanych z ich obsada kadrową. Zaangażował się w działania mające na celu doprowadzenie do szybkich awansów asystentów i adiunktów psychologów z byłej WSP. Na tle awansowania na docentów doktorów nie posiadających habilitacji doszło do konfliktu z rektorem Popiołkiem. Innym powodem rozbieżności pomiędzy prof. Pieterem a rektorem było dyskryminujące traktowanie byłych pracowników administracyjnych WSP przez nową administrację UŚ.

Po likwidacji WSP zmniejszyły się obowiązki administracyjne prof. Pietera, dzięki czemu mógł ponownie poświęcić więcej czasu pracy badawczej. Prowadził tylko wykłady z psychologii ogólnej. W roku akademickim 1968/1969 podjął starania o zwolnienie z części obowiązków dydaktycznych, które ograniczył do seminariów magisterskich i doktoranckich. Uzyskał zwolnienie z obowiązków delegata do senatu UŚ. Priorytetem stało się dla

94 Archiwum Państwowe w Katowicach [dalej: AP Katowice], KW PZPR w Katowicach. Wydział Oświaty, Nauki i Kultury. Projekt połączenia WSP z Filią UJ w Katowicach, sygn. 301/XVI/23, k. 75-81.

95 Rozporządzenie Rady Ministrów o utworzeniu Uniwersytetu Śląskiego w Katowicach, Dz. U. RP 1968, nr 18, poz. 116.

96 J. Pieter, Czasy i ludzie, t. 2, s. 440; M. Dyba, Śląskie Fundacje Szkół Wyższych, s. 16.

97 AP Katowice, KW PZPR w Katowicach. Protokół z posiedzenia egzekutywy KW PZPR w Katowicach z dn. 14 VIII 1968, sygn. 301/IV/534, k. 11; S. Fertacz, Kalendarium, [w:] Wyrósł z dobrego drzewa, s. 19.

98 S. Fertacz, Na drodze do uniwersytetu, s. 64.

99 AP Katowice, KW PZPR w Katowicach, Wydział Nauki, Oświaty i Kultury. Program obchodów uroczystości otwarcia I roku akademickiego w Uniwersytecie Śląskim, sygn. 301/XVI/54, k. 130-134.

100 Zarządzenie Ministra Oświaty i Szkolnictwa Wyższego z dn. 26 czerwca 1969 w sprawie struktury organizacyjnej Uniwersytetu Śląskiego w Katowicach, Dz.U. MOiSW 1969, nr A-7, poz. 69; Pieter Józef, prof. dr. hab. (biogram), s. 283. 
niego doprowadzenie do habilitacji swoich adiunktów. Prof. Pieterowi nie udało się stworzyć własnej szkoły naukowej. Po latach wspominał:

Stało się tak nie z defektów mej metody nauczania i kształcenia kadr, lecz z przypadkowości doboru mych współpracowników - na co przeważnie wpływu nie miałem - i z charakteru mych problemów teoretycznych, leżących przeważnie poza obrębem psychologii wychowawczej ${ }^{101}$.

Bardzo ostrożnie podchodził do kwestii nie tylko doktoratów ale również habilitacji i profesur. Zawsze oceniał dorobek naukowy kandydatów. Nie zwracał uwagę na ich powiązania polityczne.

Dochodziło do dalszych nieporozumień z władzami rektorskimi. Między innymi administracja uczelni zaprzepaściła możliwość wyjazdu profesora Pietera na Międzynarodowy Kongres Historii Nauki w Moskwie w sierpniu 1971 r. Podobnie zakończyła się sprawa wyjazdu na międzynarodowe seminarium zorganizowane w 1972 r. przez Österreichisches College przy Uniwersytecie Wiedeńskim. Władze rektorskie odrzucały wszystkie jego wnioski wyjazdów zagranicznych, m.in. do Instytutu Psychologii J.J. Rousseau przy Uniwersytecie Genewskim. Prof. Pieter o taki stan rzeczy obwiniał rektora, prof. Popiołka ${ }^{102}$.

Po odwołaniu, przed upływem kadencji, rektora Popiołka we wrześniu 1972 r. rektorem został prof. Henryk Rechowicz ${ }^{103}$. Tym samym zmienił się stosunek władz rektorskich do prof. Pietera. W 1974 r. z inicjatywy rektora został odznaczony Krzyżem Komandorskim z Gwiazdą Orderu Odrodzenia Polski. W następnym roku na wniosek Rechowicza otrzymał nagrodę ministra Szkolnictwa Wyższego za podręcznik akademicki Historia psychologii wydany przez PWN ${ }^{104}$. W 1976 r. wpisano go do księgi zasłużonych dla województwa katowickiego. W tym samym roku prof. Rechowicz zaproponował prof. Pieterowi autorską współpracę z kwartalnikiem „Zaranie Śląskie”. W 1977 r. odznaczony został Sztandarem Pracy I klasy. Gesty te prof. Pieter odbierał jako docenienie jego dawniejszych starań o utworzenie Uniwersytetu Śląskiego oraz zasług dla rozwoju naukowego Górnego Śląska ${ }^{105}$.

1 września 1974 r. prof. Pieter przeszedł na emeryturę ${ }^{106}$. Nie zrezygnował natomiast z pracy naukowej. Jednakże jego możliwości wydawnicze stopniowo zanikały, co było rezultatem nieporozumienia z Wydawnictwem Ossolineum oraz Państwowym Wydawnictwem Naukowym. W tym samym roku prof. Pieter podjął prace nad monografią zatytułowaną Krytyka ocen i recenzje prac naukowych. Ukazała się ona jednak dopiero po trzech latach, co było skutkiem negatywnej recenzji ze strony prof. M. Mazura, który zarzucił autorowi zignorowanie marksizmu. Rok 1976 stanowił kres współpracy prof. Pietera z wydawnictwami naukowymi. Zastanawiał się, czy nie zakończyć swojej pracy

101 J. Pieter, Czasy i ludzie, t. 2, s. 475.

102 Ibid., s. 458-462.

103 Odwołanie prof. Kazimierza Popiołka z funkcji rektora Uniwersytetu Śląskiego w ocenie jego następcy prof. Henryka Rechowicza, [w:] Wyrósł z dobrego drzewa, s. 323.

104 Muzeum w Skoczowie, Nagroda z dnia 1.10.1975 Ministra Nauki, Szkolnictwa Wyższego i Techniki za osiągnięcia $w$ dziedzinie autorstwa wyróżniających się podręczników dla studentów.

105 J. Pieter, Czasy i ludzie, t. 2, s. 474.

106 Muzeum w Skoczowie, Pismo ministra Nauki, Szkolnictw Wyższego i Techniki z dnia 12.06.1974 o rozwiązaniu stosunku służbowego w związku z przejściem na emeryturę; Podziękowanie z dnia 16.09.1974 Ministra Nauki, Szkolnictwa Wyższego i Techniki za wieloletnią pracę w związku z przejściem na emeryturę; Pieter Józef, prof. dr. hab. (biogram), s. 282. 
naukowo-pisarskiej. Na dodatek pogorszył się jego stan zdrowia i musiał poddać się hospitalizacji w klinice Śląskiej Akademii Medycznej. W związku z chorobą, był zmuszony ograniczyć prace pisarskie. Podjął prace nad Światopoglądem humanisty. Kontynuował również rozpoczęte w 1962 r. pisanie pamiętników zatytułowanych Czasy i ludzie. Nadal był redaktorem „Chowanny"107.

Prof. Pieter był aktywnym członkiem wielu towarzystw i komitetów naukowych, m.in.: Śląsko-Dąbrowskiego Towarzystwa Przyjaciół Nauk, Śląskiego Instytutu Naukowego w Katowicach, Komitetu Nauk Pedagogicznych i Psychologicznych PAN ${ }^{108}$, Komitetu Naukoznawstwa PAN ${ }^{109}$, Komisji Nauk Pedagogicznych PAN ${ }^{110}$ i Komisji Socjologicznej Krakowskiego Oddziału PAN ${ }^{111}$, Rady Naukowej Zakładu Historii Nauki i Techniki PAN ${ }^{112}$, Oddziału PAN w Katowicach, Towarzystwa Wiedzy Powszechnej. Był członkiem Rady Naukowej Śląskiego Instytutu Naukowego ${ }^{113} .24$ września 1949 r. zorganizował w Katowicach oddział Polskiego Towarzystwa Psychologicznego, którego przewodniczącym był do 1956 r. ${ }^{114}$

Zajmował się problemami filozoficznymi, podstawami procesu wychowania, zagadnieniami kształcenia nauczycieli oraz humanizowaniem Górnego Śląska. W pojmowaniu nauki oraz w metodyce badawczej prof. Pieter był pod wpływami szkoły lwowsko-warszawskiej. Charakteryzował się powagą w traktowaniu spraw nauki i obowiązków akademickich. Precyzyjnie przekazywał myśli. Był wymagający nie tylko wobec studentów czy też podwładnych i współpracowników, lecz również samego siebie ${ }^{115}$. Napisał ponad 200 publikacji naukowych, w tym ponad 40 książek z pedagogiki i psychologii ${ }^{116}$. Część prac została wydana już po jego śmierci. Był promotorem ponad 180 prac dyplomowych magisterskich na Uniwersytecie Łódzkim, Uniwersytecie Warszawskim, Akademii Wychowania Fizycznego w Warszawie, Państwowej Wyższej Szkole Pedagogicznej w Katowicach oraz Uniwersytecie Śląskim. Wypromował 20 doktorantów, spośród których 5 zrobiło habilitację $^{117}$.

Został uhonorowany Złotą Oznaką „Zasłużonemu dla Województwa Katowickiego” (1958 r.), Krzyżem Kawalerskim Orderu Odrodzenia Polski (1958 r.) ${ }^{118}$, Złotą Odznaką „Za-

107 Muzeum w Skoczowie, Pismo z dnia 06.10.1973 z podziękowaniami od przewodniczącego Prezydium Wojewódzkiej Rady Narodowej w Katowicach Jerzego Zietka z okazji 15-lecia „Chowanny”; Pismo Kuratora Oświaty i Wychowania w Katowicach - z dnia 16.06.1980 z podziękowaniami za wieloletni trud redagowania "Chowanny".

108 Muzeum w Skoczowie, Pismo z dnia 08.04.1969 o powołaniu na członka Komitetu Nauk Pedagogicznych i Psychologicznych PAN w Warszawie.

109 Muzeum w Skoczowie, Pismo z dnia 10.06.1969 o powołaniu w skład Komitetu Naukoznawstwa PAN.

110 Muzeum w Skoczowie, Pismo z dnia z dnia 28.03.1958 o powołaniu na członka Komisji Nauk Pedagogicznych PAN Odział w Krakowie; Pismo z dnia 21.04.1966 z powołaniem na członka Komisji Nauk Pedagogicznych Polskiej Akademii Nauk Oddział w Krakowie.

111 Muzeum w Skoczowie, Pismo z dnia z dnia 12.06.1969 o powołaniu na członka Komisji Socjologicznej PAN Odział w Krakowie.

112 Muzeum w Skoczowie, Powołanie w skład Rady Naukowej Zakładu Historii Nauki i Techniki PAN w Warszawie ze stycznia 1970.

113 E. Pieter-Kania, op. cit., s. 11.

114 Muzeum w Skoczowie, Dyplom z dnia 11.10.1979 Polskiego Towarzystwa Psychologicznego Oddziału w Katowicach z okazji 30-lecia działalności.

115 Cz. Głombik, Pasje naukowe profesora Józefa Pietera, [w:] Prof. zw. dr. hab. Józef Pieter. Działalność i dzieła. Materiaty posesyjne, s. 122.

116 Pieter Józef, prof. dr. hab. (biogram), s. 283.

117 E. Pieter-Kania, op. cit., s. 10.

118 Muzeum w Skoczowie, Legitymacja z 22.07.1958 odznaczenia Krzyżem Kawalerskim Orderu Odrodzenia Polski. 
służonemu w Rozwoju Województwa Katowickiego" (1961 r.) $)^{119}$, Krzyżem Komandorskim Polonia Restituta (1964 r.) $)^{120}$, Odznaką Tysiąclecia Państwa Polskiego (1965 r.) ${ }^{121}$, Złotą Oznaką ZNP (1967 r.) $)^{122}$, Medalem Komisji Edukacji Narodowej (1968 r.) $)^{123}$, Złotą Oznaką za Zasługi dla Uniwersytetu Śląskiego (1973 r.) ${ }^{124}$, Krzyżem Komandorskim z Gwiazdą Orderu Odrodzenia Polski (1974 r.) ${ }^{125}$, Orderem Sztandaru Pracy I Klasy (1977 r.) ${ }^{126}$, Nagrodą 35-lecia PRL - Wojewódzkiej Rady Narodowej i Urzędu Wojewódzkiego w Katowicach (1979 r.), Tytułem Honorowym Zasłużonego Nauczyciela PRL (1983 r.) ${ }^{127}$, Śląską Nagrodą im. Juliusza Ligonia (1986 r.) $)^{128}$.

W życiu naukowym prof. Pieter niezwykle mocno cenił sobie niezawisłość intelektualną, co wyrażało się zwłaszcza krytyczną postawą wobec wszelkich autorytetów. Odrzucał z całą stanowczością stanowiska i zapatrywania autorytarnie narzucone ${ }^{129}$. Uważał się za wolnomyśliciela w sensie nie religijnym, lecz filozoficznym. Równie mocno, jak niezawisłość intelektualną, cenił sobie niezawisłość moralną. Dotyczyła ona określonych zasad postępowania z ludźmi oraz wobec ludzi, jak również oceniania cudzego postępowania na podstawie faktów i zgodnie z zasadami moralnymi uznanymi przez niego za słuszne, a nie na podstawie czyichś żądań i opinii ${ }^{130}$.

W pierwszym okresie jego działalności naukowej, tzw. „scjentystycznym”, można zauważyć u niego wielką wiarę w racjonalność i potęgę metody naukowej, w rolę techniki. Formułuje wtedy postulaty „techniki moralnej”, regulującej relacje między ludźmi. Opowiada się za „ścisłością i eksperymentowaniem jako podstawową metodą dla wszelkich nauk, w tym humanistycznych". Prowadził pionierskie badania aktywności psychomotorycznej oraz rozpoczął prace nad konstrukcją instrumentów do badań uzdolnień ruchowych i nabywania sprawności ruchowych.

W drugim okresie skupia się na problemach życiowych, odchodzi od radykalnych deklaracji metodologicznych. Przesuwa akcent i zainteresowania z metod na problemy, które mają charakter całościowy, niejako globalny, zmierzają w kierunku badania całościowych faktów życia, większych jego obszarów. Skupia się na problemach funkcjonowania nauki, jej organizacji, ocenianiu w nauce. Bardziej interesuje się ludźmi tworzącymi naukę, niż samymi technicznymi metodami. Celem prof. Pietera było stworzenie nowej dyscypliny

119 Muzeum w Skoczowie, Legitymacja z dnia 17.07.1961 nadania Złotej Odznaki Zasłużonemu w Rozwoju Województwa Katowickiego.

120 Muzeum w Skoczowie, Legitymacja z dnia 22.07.1964 odznaczenia Krzyżem Komandorskim Orderu Odrodzenia Polski.

121 Muzeum w Skoczowie, Legitymacja Odznaki Tysiąclecia Państwa Polskiego.

122 Muzeum w Skoczowie, Legitymacja z dnia 09.10.1967 nadania Złotej Odznaki ZNP.

123 Muzeum w Skoczowie, Pismo Ministerstwa Oświaty $i$ Wychowania z dnia 14.11.1968 o przyznaniu Medalu Komisji Edukacji Narodowej; Legitymacja z dnia 22.11.1968 „Medalu Komisji Edukacji Narodowej”.

124 Muzeum w Skoczowie, Legitymacja z dnia 13.10.1973 przyznania Złotej Odznaki za zasługi dla Uniwersytetu Śląskiego z dnia 13.10.1973.

125 Muzeum w Skoczowie, Legitymacja z dnia 18.07.1974 odznaczenia Krzyżem Komandorskim z Gwiazdą Orderu Odrodzenia Polski z dnia 18.07.1974.

126 Muzeum w Skoczowie, Legitymacja z dnia 08.09.1977 nadania Orderu Sztandaru Pracy I KL.

127 Muzeum w Skoczowie, Dyplom z dnia 21.09.1983 - Zasłużony Nauczyciel PRL; Legitymacja z dnia 21.09.1983 do tytułu „Zasłużony Nauczyciel Polskiej Rzeczpospolitej Ludowej”; Muzeum im. Gustawa Morcinka w Skoczowie.

128 Muzeum w Skoczowie, Dyplom nagrody im. Juliusza Ligonia z grudnia 1986 przyznanej przez Stowarzyszenie PAX Zarząd Wojewódzki w Katowicach; E. Pieter-Kania, op.cit., s. 11.

129 J. Pieter, Czasy i ludzie, t. 3, s. 575.

130 Ibid., s. 581. 
humanistycznej, dzięki której można byłoby skutecznie oddziaływać na ludzi. Poddał dotychczasowe dyscypliny rzeczowej krytyce na tle ich „oderwania od życia praktycznego, zbytniej abstrakcyjności i charakteru teoretycznego oraz braku ścisłości, a także braku efektywności, spowodowanego brakiem oparcia w ścisłej ogólnej wiedzy"131. W praktyce stworzenie biografii ogólnej było nadto abstrakcyjne, zbyt ogólne, a tym samym niepraktyczne. Przyczyn tego można się doszukiwać w przyjęciu przez niego scjentystycznej i pozytywistycznej orientacji jako kierunku rozwoju wszystkich dyscyplin humanistycznych. Jest prekursorem psychologii rozwojowej na przestrzeni życia (life-span psychology).

Zmieniła się nieco terminologia tej dziedziny, mówi się w niej o psychobiografiach, tworzone są modele zmian, przekształceń psychicznych, prawidłowościach i specyfice rozwiązywania problemów życiowych. Do kluczowych pojęć należą koncepcje „ważnych wydarzeń życiowych” i „kryzysów życiowych lub osobistych”, poprzez które kształtuje się indywidualność i tożsamość podmiotów ${ }^{132}$.

Prowadzone przez prof. Pietera badania psychobiograficzne posiadają wiele wspólnego z powstałą w drugiej połowie XX w. life-span psychology, a nawet wykraczają poza jej założenia.

Prof. Pieter był również pionierem badań w dziedzinie psychologii o orientacji kognitywistycznej. Kładł silny nacisk na osobiste doświadczenie człowieka i wynikającą z doświadczenia wiedzę osobistą. Jako jej źródło widział nie tyle konkretne doświadczenia, lecz doświadczenia pozornie wspólne, instytucjonalne, które są w specyficzny sposób przyswajane i uwewnętrzniane przez człowieka. Zauważał dominujący wpływ szkoły na procesy kreowania wiedzy indywidualnej i jej zastosowania w życiu podmiotu ${ }^{133}$.

Prof. Pieter przedkładał działanie i doświadczanie nad abstrakcyjną naukę. Zagadnienia będące jego przedmiotem zainteresowania widział w rzeczywistych kontekstach. Ważne było dla niego, czyja to wiedza i o czym.

Józef Pieter zmarł po ciężkiej chorobie 3 marca 1989 r. w wieku 85 lat ${ }^{134}$.

\section{Bibliografia}

\section{Źródła archiwalne}

Muzeum im. Gustawa Morcinka w Skoczowie: Materiały dotyczące życia prof. Józefa Pietera. Archiwum Uniwersytetu Śląskiego w Katowicach: Kronika PWSP w Stalinogrodzie 19501953; Kronika WSP 1956-1962; Kronika WSP 1 stycznia 1963 - grudzień 1964; Sprawozdania, przemówienia inauguracyjne 1964-1969.

Archiwum Państwowe w Katowicach: KW PZPR w Katowicach, Wydział Nauki, Oświaty i Kultury.

131 M. Adamiec, Idee biografizmu Prof. Józefa Pietera a współczesne idee psychobiografii, [w:] Prof. zw. dr hab. Józef Pieter. Działalność i dzieła. Materiały Posesyjne, s. 21-54.

132 M. Adamiec, Człowiek i psychologia: profesor Józef Pieter i jego dzieło (1904-1989), s. 5-6. [tekst niepublikowany, udostępniony przez autora]

133 Ibid., s. 6.

134 Cz. Głombik, op.cit, s. 121. 


\section{Źródła drukowane}

Dziennik Ustaw Rzeczypospolitej Polskiej (1950, 1955, 1956, 1965, 1968).

Dziennik Urzędowy Ministerstwa Oświaty $(1957,1964)$.

Dziennik Urzędowy Ministerstwa Oświaty i Szkolnictwa Wyższego(1969).

\section{Źródła prasowe}

"Dziennik Zachodni” (1952, 1961).

"Gazeta Wyborcza" (1996).

"Słowo Powszechne" (1959).

„Trybuna Robotnicza” (1957, 1965).

„Wieczór" (1965).

\section{Literatura przedmiotu}

Adamiec M., Człowiek i psychologia: profesor Józef Pieter, [w:] Śląscy uczeni. O tych co odeszli, cz. 2, red. J. Malicki, J. Śliwiok, M. Skóra, Katowice 2004, s. 21-54.

Bobrowska-Nowak W., Wkład prof. Józefa Pietera w rozwój pedagogiki i psychologii wychowania i nauczania oraz historii psychologii, [w:] Prof. zw. dr. hab. Józef Pieter. Działalność i dzieła. Materiały posesyjne, Katowice 1999, s. 13-20.

Błońska W., Dokonania organizacyjne i dydaktyczne Prof. dr. hab. Józefa Pietera w instytucjach i szkołach wyższych, [w:] Prof. zw. dr. hab. Józef Pieter. Działalność i dzieła. Materiały posesyjne, Katowice 1999, s. 67-72.

Brożek L., Czupryna M., Gospodarze Szkoły (sylwetki dyrektorów), [w:] Księga Pamiątkowa Polskiego Gimnazjum Macierzy Szkolnej w Cieszynie obecnie Liceum Ogólnokształcącego imienia Antoniego Osuchowskiego w Cieszynie wydana z okazji 100. rocznicy założenia szkoły, Cieszyn 1995, s. 2-249.

Czech A., Starania o uniwersytet w Katowicach w 1945 roku, [w:] Prof. zw. dr. hab. Józef Pieter. Działalność i dzieła. Materiały posesyjne, Katowice 1999, s. 115-120.

Chodakowska J., Geneza Uniwersytetu Śląskiego w Katowicach, „Rozprawy z dziejów oświaty" t. 17, 1974.

Dobrowolski T.J., Geneza i początki Instytutu Pedagogicznego w Katowicach, Katowice 1960.

Drogoń A., Polityczne i społeczne uwarunkowania w procesie powstawania szkolnictwa wyższego w Katowicach, [w:] W 143. Rocznicę uzyskania praw miejskich. W 40-lecie powstania Uniwersytetu Śląskiego - szkolnictwo i nauka na Górnym Śląsku, red. A. Barciak, Katowice 2009, s. 116-167.

Drogoń A., Życie społeczne i polityczne Uczelni - rys historyczny, [w:] Mądrość zbudowała sobie dom... Uniwersytet Śląski 1968-2008. Dzieje, dokumentacja, źródła, red. A. Barciak, Katowice 2008.

Dyba M., Śląskie Fundacje Szkół Wyższych, [w:] Wyrósł z dobrego drzewa... Uniwersytet Śląski 1968-1998. Fakty, dokumenty, relacje, Katowice 1998.

Fertacz S., Na drodze do uniwersytetu, [w:] Mądrość zbudowała sobie dom... Uniwersytet Śląski 1968-2008. Dzieje, dokumentacja, źródła, red. A. Barciak, Katowice 2008.

Fertacz S., Wydarzenia Marca '68 w uczelniach katowickich, [w:] Katowice w minionej rzeczywistości, red. A. Barciak, Katowice 2006. 
Głombik Cz., Obecność filozofa. Studia historycznofilozoficzne o Władysławie Tatarkiewiczu, Katowice 2005.

Głombik Cz., Pasje naukowe profesora Józefa Pietera, [w:] Prof. zw. dr. hab. Józef Pieter. Działalność i dzieła. Materiały posesyjne, Katowice 1999, s. 121-123.

Goriszowski W., Profesor Józef Pieter (1904-1989) - psycholog, pedagog i organizator życia naukowego na Śląsku, „Nauczyciel i Szkoła” 2001, nr 1-2.

Kowolik P., Józef Pieter (1904-1989) - psycholog, pedagog, filozof, "Nauczyciel i Szkoła” 2004, nr 1-2.

Mayer J., Śląsko-Dąbrowskie Towarzystwo Przyjaciół Nauk, "Zaranie Śląskie” 1957, z. 1-2.

Memoriał w sprawie założenia Uniwersytetu w województwie śląsko-dąbrowskim, Katowice 1945.

Pieter Józef, prof. dr. hab. (biogram), [w:] „Non omnis moriar. Zmarli Pracownicy Uniwersytetu Śląskiego w Katowicach 1968-2008, red. A. Barciak, Katowice 2008, s. 282.

Pieter J., Czasy i ludzie, t. 1-3, Katowice 2004.

Pieter J., Kilka uwag w sprawie organizacji pracy naukowej na Śląsku, "Zaranie Śląskie" 1929, nr 4, s. 197-215.

Pieter J., Pienwsza wyższa uczelnia polska na Śląsku, „Zaranie Śląskie” 1957, z. 1-2, s. 42-54.

Pieter-Kania E., Droga życia prof. zw. dr. hab. Józefa Pietera - mojego Ojca, [w:] Prof. zw. dr. hab. Józef Pieter. Działalność $i$ dzieła. Materiały posesyjne, Katowice 1999, s. 9-12.

Salamon M., Powstanie Uniwersytetu Śląskiego, [w:] Katowice. W 143. Rocznicę uzyskania praw miejskich. W 40-lecie powstania uniwersytetu śląskiego - szkolnictwo i nauka na Górnym Śląsku, red. A. Barciak, Katowice 2009, s. 43-56.

Zarembina W., Powstanie i rozwój Wyższej Szkoły Pedagogicznej w Katowicach, [w:] Wyższa Szkoła Pedagogiczna w Katowicach 1950-1968, red. A. Jarosz, A. Jendrysik, Katowice 1971.

dr hab. Zbigniew Hojka (ur. 1962 r.), absolwent studiów historycznych na Uniwersytecie Śląskim (1988 r.); od 1987 r. pracownik Instytutu Historii UŚ; w 1995 r. obronił pracę doktorską pt. Zespolona administracja rządowa $i$ autonomiczna w województwie śląskim (1922-1939) - geneza, struktura organizacyjna i zakres działania; w 2007 r. habilitował się na podstawie pracy pt. Polski Ruch zawodowy w województwie śląskim w latach 1922-1939. Oblicze polityczne. Zainteresowania badawcze: historia Polski w okresie dwudziestolecia międzywojennego ze szczególnym uwzględnieniem dziejów Śląska, historia Kościoła katolickiego, ustrój polskiego Śląska w dwudziestoleciu międzywojennym, propaganda wyborcza, savoir vivre, szlaki turystyczne w Polsce. Przewodniczący Rady Muzealnej Muzeum w Chorzowie, członek Zarządu Górnośląskiego Towarzystwa Przyjaciół Nauk. e-mail: zbyszek_hojka@o2.pl

Data zgłoszenia artykułu: 3 czerwca 2019

Data przyjęcia do druku: 27 października 2019 